\title{
Difficulties Prevent Jordanian Women Participation in Political Life in Light of Some Social Variables
}

\author{
Alaa Zuhheir Al- Rawashdeh ${ }^{1}$, Asmaa Ribhi Al Arab ${ }^{1}$ \& Ali Mohammad Ali Al-Shboul ${ }^{2}$ \\ ${ }^{1}$ Department of Social Sciences, Ajlun University College, AL-Balqa' Applied University, Ajlun, Jordan \\ ${ }^{2}$ Department of Basic Sciences, AL-Huson University College, AL-Balqa' Applied University, Irbid, Jordan \\ Correspondence: Ali Mohammad Ali Al-Shboul, Department of Basic Sciences, AL-Huson University College, \\ AL-Balqa' Applied University, P. O. Box 50, AL-Huson, 21510, Irbid, Jordan. Tel: 962-77-704-9699. E-mail: \\ Dr.alish68@yahoo.com
}

Received: April 17, 2012

doi:10.5539/ass.v8n10p208
Accepted: May 15, 2012 Published: August 1, 2012

URL: http://dx.doi.org/10.5539/ass.v8n10p208

\begin{abstract}
This study dealt with the most important difficulties that prevent Jordanian women participation in political life, the study used a purposive sample consisted of 80 pioneers women in north region governate for the year 2011 . A questionnaire consisted of four aspects that covers the difficulties prevent Jordanian women from participating in political life. The following conclusions were drawn from this study: the social, the cultural difficulties are the most important factors that prevent Jordanian women participation in political life.

Finally and in light of the results the study came up with some recommendations such as: working on the awareness of society to change its believes regarding women participation on political life and to work on improving the economical situation of the women (economical empowerment).
\end{abstract}

Keywords: women, Jordanian women, political life, social variables, Jordan

\section{Introducation}

The Jordanian woman forms a class that exceeds half of the population in which the Jordanian woman played a limited role in life aspects where the surrounding culture the traditional view at that time and the spread or illiteracy and ignorance were some of the challenges that faced Jordanian woman and presented her from rising her potential in occupying the administrative positions and practicing politics.

At the present time where the world is developing and man has endless ambition considering that the Jordanian society is unsupported from the world due to technology advancement and the development of communication means- the Jordanian woman seeked for democracy and achieving equality with the man which provided her equal opportunities in work and education, but these efforts were ineffective because of woman dependence and the masculine society culture under the traditional political systems given for men. These systems under estimate woman administrative ability and her political participation when we speak about the reality of woman political participation, we don't mean by that the parliament elections, the parliament membership or the ministry or any political position but we mean the activities that the woman carries out to change her circumstance. These activities take the form of decisions and actions that guarantee a special status for the woman not only in the family but also in the society (Ashour, 2003).

Due to the democratic advancement occurring in the world where the woman political participation is considered an international standard for Judging the democratic advancement of the countries and the Jordanian woman is enjoying her political and civil rights such as freedom or speech and woman quota system, this issue gained importance to determine the difficulties that face the woman at the present time and that limit her political participation in the Jordanian society, especially that we are approaching municipalities, council elections and the parliament in which they form a rich environment to a dress and discuss this issue

ers these questions in just a few pages and, by summarizing the relevant arguments and the past evidence, gives the reader a firm sense of What was done and wh y (Beck \& Sales, 2001). 


\subsection{Study Problem}

The study aims to identify the most important obstacles and difficulties that limit the political participation of the Jordanian woman in general and the pioneer woman in specific at the political and administrative positions in the 21 th century despite the democratic atmosphere and political stability that Jordan enjoys.

This study aims to:

1- Determine the most important social and cultural difficulties that face the Jordanian woman in the political participative.

2- Determine the most important economical difficulties that face the Jordanian woman in the political life.

3- Determine the most important political and legal difficulties that face Jordanian woman in the political life.

4- Determine the media role in supporting woman political participation.

5- Determine the effect of some social variables (Social status, the academic degree, job, age, monthly income, administrative level and family member's number).

\subsection{Study Questions}

The Study questions focus on the difficulties that face the woman political participation in our Jordanian society and they address the most significant difficulties in the different aspects which limit her political participation. They form the measure that we will address as follows:

1- What are the most important social and cultural difficulties that face Jordanian woman in the political life from the view point or study sample (pioneer woman)?

2- What are the most important legal and political difficulties that face the Jordanian woman in the political life from the view point of the study sample (pioneer woman)?

3- What are the most important difficulties that face the Jordanian woman in the political life from the view point of study sample (pioneer woman)?

4- What are the most important media difficulties that face the Jordanian woman in the political life from the view point of study sample (pioneer woman)?

5- What is the effect of some social variables (social status, academic degree, job, age, monthly incomeadministrative level and family members number) on these difficulties?

\subsection{Study Significance}

The study significance lies in that it examined specifically that most important obstacles and difficulties which limit Jordanian woman participation in the political life with regard to the low level or participation, especially if it is compared to the developed level that the Jordanian society witnesses in all aspects.

This participation didn't copy with the developments occurring in the society; also, the study significance comes from its dependence on one of the most important subject in the research field in woman sociology and social service in woman field and the political participation. The woman forms a great percentage of the society. Practically, this study will benefit the decision makers to determine the most important difficulties that prevent and limit woman participation in the social life in general and politics in specific. This study aims to determine the difficulties for Jordanian woman participation in the political life within the family field which is one of the social services domains.

\section{Theoretical Background}

\subsection{Procedural Definitions}

1- The political participation: The public work with all its forms which include elections and the nomination for the municipality and parliament council, the occupation of decision making position, the participation in political parties and the action to integrate national woman agenda in the political programs for the candidates and parties, (saleh, 2004).

2- The political participation: A set of collective activities carried out by citizens and have the capacity to give them influence on the course of the political system (AL-Tajkoni- 1999).

3- Pioneer Woman: The woman who works now in any administrative position or worked in an administrative position or played a role in successful works and activates.

4 - Pioneer: The woman doesn't stand passive regarding the events but she takes the initiative in order to make the correct decision and position in the difficult times. She is also a woman who takes the lead instead or living 
in the shadoms (Al-Hadad, 2005).

5- The difficulties: The problems that hinder political development especially in the developing countries. These problems have negative effects on the developmental process (Al-Hadad, 2005) as the political social, economical and cultural factors.

6- The political life: The importance of determining the political life lies in the integration or political life (political parties, parliament and the legislative committees) and the public life (unions - organizations). This integration has led to a certain situation pushed the woman to participate in the public life through her participation in the political life (Hussein, 2005).

\subsection{The Political Participation (The Forms Motive, Position, the Affecting Factors)}

\subsubsection{Political Participation Forms}

The first form: includes the familiar and organized activities:

* The registration in the elections lists.

* Voting.

* The search for political media.

* The political conversations:

* The registration in a party.

* The attendance of political conferences and meetings.

* The participation in an election campaign.

The second form: includes the temporary activities that express a situation or an event characterized in protests, strikes and violent actions. These activities aren't necessarily illegal but they can be legitimate and legal as peaceful protests.

\subsubsection{Political Participations Motives}

The motives that encourage individuals to participate in the political process vary- some individuals have the desire to achieve personal interest like getting money or a position on the other hand, others participate to confirm the loyalty for their country while some have the personal and the public motive to participate. In sum the individuals aim to achieve personal or public interest regardless its form (economical social ....etc) for participating in the political process (Ashour, 2003).

\subsection{Woman Motives to Participate in the Public and Political Affairs}

1- The woman now realizes more the difficulties and the contradictions that surround her life which in tern encouraged her to change her circumstances.

2- The active woman in the political field draw attention to woman issues and made woman on effective agent in decision making.

3- Woman's success in the voluntary work which made her more confident to participate in the political life.

4- The success that woman achieved in public life to the excellence or money woman (Faraj, 1996).

There are other reasons for woman participation in the political activities:

1- The family belief that woman must be in the masculine responsibility positions.

2- The model that successful woman represented in the political work.

3- The woman sense or her special abilities and skill that can be used in the political work.

4- The woman's ambition to play more active role in the society.

5 - The woman confidence in her ability to shed light on the important social issues from her view point.

6- The woman un satisfaction for the current situation and her confidence to change through the public work (Naqatashard, 2001).

\subsection{Functions of the Political Participation}

The functions of the political participation are restricted to two main functions:

1- The acknowledgment of leader's legitimacy which facilitates practicing their responsibilities. The ability or the competitive elections to acknowledge legitimacy seems higher than abstract rotting processes that lack 
freedom entices where there is a single official candidate. For this reason, the multiple democracies fear low participation due to voting cease. The researcher found that this function is characterized fundamentally through a limited form of the participation legal forms that is the election style or the voting style.

2- The use of the interference in leaders, selection where the political participation can affect the standing balance between the government and the political parties in the country. This issue provokes the government to respond to this participation even it, it is variable from one case to another, and consequently, the individuals can affect the country policies (Ashour, 2003).

\subsection{The Factor Affecting the Political Participation}

The political participation is affected by various factors that contribute in shaping the size of participation by the citizens. The effect of these factors varies from one country to another due to the special characteristics for the people of each country. We can say that the most important factors are as follow:

1- The demographic and social factors such as sex, age and residency.

2- The economical factors such as the monthly income.

3- The cultural factors such as education level the ideological thinking and the political culture (Ashour, 2003).

\subsection{The Difficulties That Limit the Political Participation of the Jordanian Woman}

First: the political and cultural difficulties.

These difficulties relate to some cultural and social attitudes where:

1- The dominant customs and traditions indicate that the woman is a weak human being who doesn't have the ability to bear the burden. These traditions say that woman work never exceeds family and home.

2- The society culture is a masculine culture where man is considered the most capable of making the public policy decision and that he has unlimited access to all work domains.

3- The dominant pattern of values and traditional attitudes which indicate that woman is not capable isn't capable of carrying out decision making responsibilities. They say that woman role is to lock av-ter her children and to run house affairs. In the light of this traditional view, it become difficult for the woman to reach decision making position at a wide range or even to balance house affairs and the political participation.

4- The cultural heritage that has many flows related to woman's image and her role which created doubts about her leadership abilities especially the legislating authority.

This passive view for the woman role is still affecting the public opinion that is used by the conservative social current; it is known that this traditional social structure prefers supporting the man instead of the woman.

Second: the legal and political difficulties: The woman and the political work from the law's view point:

The Jordanian constitution laid down the equality principle between the man and the woman in which the sixth article stated: "Jordanians are equal before the law and they aren't discriminator in the right and duties even if they were different in race language or religion. The word Jordanian in the law means every person who has the Jordanian nationality male or female.

The Jordanian constitution has many items that consider man and woman equal before the law and they aren't discriminated in their duties and right to establish the political parties and organizations. The constitution had also articles about woman's participation in the political parties in which the sixth article from the political parties' law no (32) 1992 stated that: Jordanians have the right to establish the political parties and to join them voluntarily. Many laws have been mandated such as: the placations law so that the woman has the right to practice elections and the nomination for the parliament membership in 1974. Also, the municipalities' law has been mandated where woman was given the right to participate in the municipality elections and the nomination in 1955. Moreover, the retirement law referees to the Jordanian man and woman in all his articles even that it had special items for the woman (Faraj, 1996).

\subsection{The Major Political and Legal Difficulties That Limit Woman Political Participation}

Woman quota system: A number of chairs have been given to the woman in the parliament elicitations in which it aimed to remove the gap between the man and the woman regarding in a quality in the political life especially the parliament elections (H-saleh, 2004). Al-Khaza'L: (2005) stated that the quota system with its current distribution never achieves justice. The law has doubled winning chances for woman in the some all electoral districts where there are no many female candidates, that is the law helped the traditional powers winning and prevented the competent woman to reach the parliament. With regard to the capital electoral districts which are 
considered the political process centre, the woman failed to reach the parliament despite getting huge number of voting's while woman in other governates won with less number of ratings.

Therefore, the quota system didn't satisfy woman ambitions. The designation of sixth chairs in the parliament is injustice for the Jordanian woman where as it will be more helpful to designate chairs for the woman according to the electoral districts in accidence to Justice and equality principle and the equality of opportunities.

The woman lacks the knowledge of her legal rights regarding the nomination for the parliament or the participation in the political process since she didn't' work to gain the political position and the experience that qualities her to run the elections with strong will and knowledge for her rights and duties.

There are no educating programs for the legal affairs especially for the woman in the schools, universities and the media and if there are- they will be general and limited.

The dominance of martial law due to the difficult political conditions which were the main reason for the woman not to participate in the political Process (Al-khaza'Li, 2005).

Third: The economical difficulties:

The woman economical dependence on the man due to her weak participation in the Jordanian labor force that doesn't exceed almost 15\%. The Jordanian woman can't afford the financial burdens for the nomination process where the nominations fees or financing (AL-Abadi, The woman and parliament elections- p16).

The inequality between the male and female candidates in financing the electoral campaigns. The experience has proved that the previous fact can be a real obstacle preventing the woman to reach the parliament especially in some districts that face lack of financial resources. Therefore, the nomination for the elections demands the woman to right its first battle with the economical problem and to make an extra effort to provide the money needed to cover the elections expenses. Also, the woman has to right as a cord battle related to the election itself. This requires.

The poor economical conditions in the Jordanian society- in general- forced the Jordanian woman to work instead of looking for have right and her public freedom (Abu-Roomi, 1995).

Fourth: The mass media difficulties:

The mass media play an important role not less than that played by the family or the school in the political process development where newspapers, radio and the television support the political attitudes and the traditional values while they broadcast news and information from the citizen to the government and vice versa. The mass media moved to transmit news and information about the scientific communities. The modern state is based on mass media as a foundation for political development and to increase sense or belonging and loyalty for the country (Al-Thaher, 1985).

The content of mass media directed to woman is about the traditional interests and roles related to the woman.

The mass media limits the man - woman relationship on a social base.

The passive role for the mass media contributes in the traditional female image that depends on the man for setting the make up tools and other extra things (Abu-Hindi, 2003).

\section{Previous Studies}

Al-KhazaLi and Nadra (2005) conducted a study titled, the woman right to participate in elected parliament's that explains the causes and the difficulties preventing the woman to reach the parliament through the public voting. The study found that there are economical, religious, political, legal reasons forms these difficulties. Also, the study reasons related to the woman herself such as the education level, the culture and her financial independence. These variables also play a major role in politically and they control her desire and ability to participate in the parliament elections. The study concluded that the quota system will encourage woman and the society members to choose the best and will allow more women to actively field in the political process. Moreover, the tribes and parties will be encouraged to nominate woman.

Abu Hindi and Hana (2003) conducted a study "The creative and psychological features for the working woman in leadership positions in Amman", the study aimed to determine the psycho-creative features for the working woman in the leadership positions in Amman. The study findings are as follow: The working woman in leadership positions in Amman posses psychological features related to society (citizenship) that came in the first order. The values related to the group came next then the individual values. The study found no significant statistical differences in the psychological level for the working in the leadership positions in Amman according to social status variable. 
The most significant creative features for the working woman in the leadership position in Amman include the problems, the initiative, flexibility and self-confidence.

Ashour (2003) carried out a study "The political participation for the Jordanian woman (1989-2001)". The study aimed to determine the reality or the political participation for the Jordanian woman during the period (1989-2001). The study was limited to one of the political participation forms for the Jordanian woman that is the Jordanian woman participation as a candidate and a voter.

The study addressed the results of female response for the years $(1989,1993$, and 1997). The study used the intentional sample and the questionnaire to deter time the attitude or the female elite and female leaderships regarding the election issue and the optimal election law for the woman. Also, the study aimed to identify the most important obstacles for the Jordanian woman participation in the electoral process.

The study concluded that the best method to enhance woman participation in the electoral process is supporting her first place than the man and to enhance the trust with the integrity or the electoral process.

Al-smadi (2002) conducted a study titled "the woman' role in the Islamic parties a comparative study between the Jordanian Islamic action association and the Lebanese's party Hizb Allah. The researcher aimed to show the preparations of the women joining to the parties and the political process despite their various responsibilities at the love of the family and the work outside the house.

The researcher conducted a field study that described the woman out lock the two parties, membership and their evaluation for the party leadership attitude and surrounding society toward their participation in the parties. Also, the researcher aimed to determine the difficulties and obstacles related to the participation in the political parties at the social economical and the political level. The study concluded that the woman in Hizb-Alah has high confidence in the party leadership while the Jordanian Islamic association didn't get the some confidence from the woman participating in the party. The study revealed a supporting attitude in side Hizb Alah regarding woman's participation while the opinions varied inside the Jordanian Islamic party toward this issue.

Mohammad and Al-Bashir (2001) conducted a study "The woman legal rights in the Jordanian personal status law". The study aimed to investigate the importance of woman legal rights in the Jordanian personal status law and the legal protection for the Jordanian woman. The researchers conducted a field study and interviews with number of lawyers, a judges and woman who have legal cases. The Study windings indication the importance of Increasing woman education, the adjustment of some legal aspects. The study also stressed the significance of woman's participation in forming the laws related to her life besides increasing woman political participation.

Al-Jasem and Manal (1999) conducted a study titled "Arab woman role in the political life.

The study aimed to examine the Arab woman status after 1968 revolution also, the study aimed to determine the attend of woman participation in the Arab liberation movement for the freedom and independence since the beginnings of the twentieth century with the increased a awareness and the refusal of the colonization. The study found that woman's claims in the national political right preceded her social claims through the national political movement.

Al-Mutairi and Muna (1997) carried out a study titled "The political rights and Islam decision regarding woman's assuming them". The study aimed to explain and determine woman's political rights in the law and Islam. The study included the religious sentences, the legal definition and the decision regarding woman participation in the elections. All the opinions and the standards evidences allowed the woman political work since Prophet Mohammad was the first to give woman their right in Bay'at Al-Aqaba.

The law provided the woman her rights and protected her, the researchers found that the public law organized the political work for men and woman and it provided sets or rights such meetings, right, the establishment of organizations, and freedom of speech and the freedom of work.

Al-zaghloula (1996) conducted a study titled "Woman's image in mass media". The Jordanian television in the period between 1-1-1992 to 31-12-1994. The study aimed to identify the woman's image in the televised drama. The study which consisted of seven chapter users the content analysis methods through the following analysis classes:

1- The woman's image at the social level.

2- The woman's image at the economical level.

3- The woman's image at the political level in the light of woman's participation in the parties, unions and the politics attitudes. 
The sample has been randomly chosen from the televised drama. Also, the study used the quantitative analysis. The study found a set of finding and the most important one are those related to the political aspect: The Percentage for woman presence in the political field was zero.

\section{The Study Came up with Some Recommendations}

The establishment of a strategy and a clear plan for mass media related to the woman and her issues, the enhancement of working woman role in the mass media, presenting the supporting media materials and distributing then- the encouragement of the good Arab programs in order to promote woman's Image and the conduction of qualifying workshops for television and radio supervisors.

Mari and Jamal carried out a study titled "The youth and the political participation in the Jordanian society". A Social study for a sample of Jordan university students. " The study aimed to analyze the youth political participation and its effect on the family either they were cultural, social and economical effects, also, the study aimed to determine the relation between these effects, the youth participation and the dominant political climate in Jordan, the study used the random sample. The study reached the following findings: There are still some fears regarding youth political participation in which the percentage of those who reported that the general circumstances don't facilitate the political participation was (50.5\%) of the sample.

Rouni and Reham (1995) conducted a study titled "The feminist movement and its role in the Jordanian society". The study aimed to study the feminist movement in the Jordanian society through examiner the organizations, the activities and the changes that the feminist movement with issued. The theoretical domain for this study focused on the most important factors that helped the feminist movement pioneers and its members to shape this movement. The study reviewed the historical sequence for the movement regarding the political, economical and social conditions that afforded this movement. The study collected two types of data:

The written material about the subject.

The information from the female pioneers of the movement as a major source in the history of Jordanian female movement. The study found that the female movement in Jordan suffers from clear conflict within its own structure. The previous fact explains the presence for two unions for the Jordanian woman instead of one union. The female movement in Jordan is a social movement that doesn't own the concept of group identity for the members at the general level. The movement depends on the group identity for the small organizations inside the movement. Also, the movement lacks the overall loyalty due to goals distraction and insufficient spread. These factors affect the awareness of the general and special goals of the movement.

Abu- Shair and Hamid (1994) conducted a study titled "The woman and the political rights in Islam". The study aimed to shed light on the opinions of these who agree or disagree with regard of woman assuming political positions in the Islamic state. The study also tried to reach the Islamic decision regarding this issue. The study used the intentional sample method for the scientists and specialists. The study findings included the efforts of the contemporary authors that are divided into two parts:

1- The first part: A team of contemporary authors who have intentionality religious majors. Those authors supported granting the woman all her political rights.

2- The second part: A team of Islamic scientist who followed the old Islamic scientist views with regard to allowing the woman to assume the private positions and preventing her from the public positions. Al-Salhi and Susan (1994) conducted a study titled "The social difficulties for the Jordanian woman's participation in the political process, a field study". The study aimed to discover the social difficulties for Jordanian woman participation in the political process. The study tried to explain the most important social difficulties for the Jordanian woman participation in the political process and how the study variables (sex social status, the educational level, age, income, years of experience and the work) degree of the social difficulties importance for the Jordanian woman participation in the political process.

The study found that the social difficulties vary according to the variance of the educational level in which those who carry higher academic qualification tend to give higher evaluation for this difficulty and vice versa. The same thing applied to the cultural difficulties. The study recommended charging the social development concepts to the woman political development. The strategic studies centre in Jordan University (1994) conducted a study titled "Jordanian attitude toward woman participation issue in the political life". The study used a random sample that consisted of (2050) participant.

The study findings indicated the following: most of the sample participants (2000) reporter that the woman should stay at home. Also, The participants reported that the man ability to make decisions exceed the woman ability and that the man political ability is higher than the woman ability. The female participants reported that 
their political participation in choosing the parliament candidate was their own decision. Most of the participants indicated difficulties for woman participation in the political life such as the society reaction for woman participation in the political life. Morn than half of the participants talked about the importance of quota system for the woman.

Al- Nasrawi and Faten (1986) carried out a study titled "The factors affecting the leading role for the woman in the Jordanian society from the view point of the male and female leaders". The study aimed to determine the factors that affect the leading role for the woman. The study sample consisted of (240) male and female leaders working in the public and private sectors. The sample was chosen by the random method. The researchers prepared a questionnaire that includes the factors affecting the woman leading role in the Jordanian society. The factor analysis determined five domains:

1- The biological factors: Factors that relate to the balance between the leadership duties and the marriage life.

2- The social factors: Factors related to the society view for the woman as a leader.

3- The Economical life: Factors that related to the financial difficulties as a result fro the leadership.

4- The psychological Factors: Factors that relate to the woman's view for herself as a leader.

5- The educational factors: factors related to the man's view for the woman as a leader.

Baur and Ling (2003) conducted a study to determine the relation between the woman Personality characters and her political participation. A questionnaire was distributed on (50) woman from different social and economical classes in the American Florida state. The study found that there is a clear variance in woman personal interests compared with different personality's patterns. Also, the study found a clear effect for the economical level in which the woman from the middle economical level in the most interested in the political issues.

\section{Study Methodology}

\subsection{The Study Approach}

The study used the social survey method and the analytical descriptive approach.

\subsection{The Study Population}

The study population consisted of the pioneer woman in the Jordanian society in the north of Jordan (Irbid, Jarash - Ajlun and Mafraq).

\subsection{The Study Sample}

The study selected (80) pioneer woman in Jordan using the intentional method, these woman practice administrative activities and successful works. The study aimed to determine these woman attitudes regarding woman's participation in the political life and the most important difficulties that face the woman in the present time.

Table 1. Sample participant's distribution according to study variables

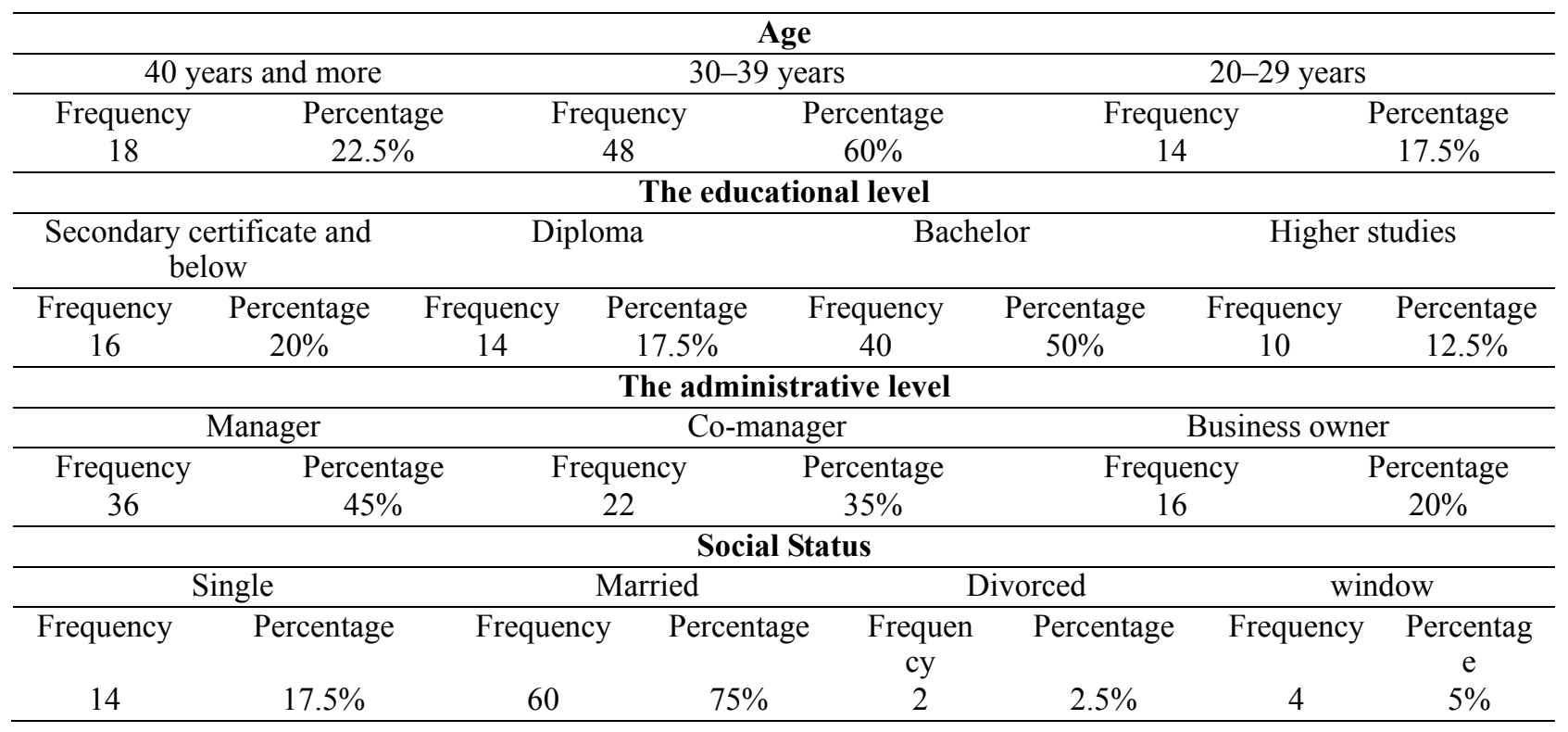




\begin{tabular}{|c|c|c|c|c|c|}
\hline \multicolumn{6}{|c|}{ Type of Job } \\
\hline \multicolumn{2}{|c|}{ Governmental } & \multicolumn{2}{|c|}{ Private } & \multicolumn{2}{|c|}{ else } \\
\hline Frequency & Percentage & Frequency & Percentage & Frequency & Percentage \\
\hline 44 & $55 \%$ & 24 & $30 \%$ & 12 & $15 \%$ \\
\hline \multicolumn{6}{|c|}{ Monthly Income } \\
\hline \multicolumn{2}{|c|}{$100-200 \mathrm{JD}$} & \multicolumn{2}{|c|}{$201-300 \mathrm{JD}$} & \multicolumn{2}{|c|}{300 and more } \\
\hline Frequency & Percentage & Frequency & Percentage & Frequency & Percentage \\
\hline 8 & $6 \%$ & 24 & $30 \%$ & 48 & $60 \%$ \\
\hline \multicolumn{6}{|c|}{ The number of Family members } \\
\hline \multicolumn{2}{|c|}{ Less than 4} & \multicolumn{2}{|c|}{$5-8$} & \multicolumn{2}{|c|}{9 and more } \\
\hline Frequency & Percentage & Frequency & Percentage & Frequency & Percentage \\
\hline 16 & $20 \%$ & $\mathbf{5 0}$ & $62.5 \%$ & 14 & $17.5 \%$ \\
\hline
\end{tabular}

5.4 The Study Tool (Validity and Reliability)

The study used a questionnaire that included for aspects from the difficulties that limit woman participation in the political life. The questionnaire was shown to a committee of arbitrators and was adjusted according to the committee suggestions. The tool validity coefficient was estimated using Alpha Cronpach Statistical test which was applied twice to a sample (12) with interval time (10 days) and it was (0.77).

\subsection{The Statistical Style}

The study used the computerized statistical system (SPSS) in which:

- The questionnaire items were estimated using the mean and the standard deviation.

- ANOVS analysis was used to determine the effect of social variables the academic degree Job, age, monthly income, the administrative level and number of family members.

\subsection{The Discussion}

This study aimed to determine the difficulties that limit the political participation for the Jordanian woman. The study examined the pioneer woman in the Northern Province yore rates. The responses for the questionnaire items were as follow:

First: the means and the standard deviations for the questionnaire items.

Table 2. The social and cultural difficulties the limit the political participation of the Jordanian woman

\begin{tabular}{clcc}
\hline No & \multicolumn{1}{c}{ Item } & Mean & Standard deviation \\
\hline 1 & $\begin{array}{l}\text { The man doesn't accept woman to be administratively } \\
\text { responsible for him }\end{array}$ & 4.11 & 1.14 \\
2 & $\begin{array}{l}\text { The woman isn't able to balance between her family } \\
\text { responsibilities and her political responsibilities. }\end{array}$ & 2.08 & 1.22 \\
3 & $\begin{array}{l}\text { The woman's lack of awareness for her role limits her } \\
\text { political participation }\end{array}$ & 3.89 & 1.52 \\
4 & $\begin{array}{l}\text { The dominant value forces the man to protect the woman } \\
\text { which decreases her freedom in taking her political } \\
\text { decisions. }\end{array}$ & 4.32 & 1.22 \\
5 & $\begin{array}{l}\text { The Jordanian woman is still working in the traditional } \\
\text { works than are an extension for her female nature. }\end{array}$ & 3.74 & 0.91 \\
6 & $\begin{array}{l}\text { The vice culture is a direct factor limiting her political } \\
\text { participation }\end{array}$ & 3.96 & 1.12 \\
7 & $\begin{array}{l}\text { The vice culture limit the nature of the job that the } \\
\text { woman can work }\end{array}$ & 4.03 & 1.05 \\
8 & $\begin{array}{l}\text { Society lack of awareness for the significance of woman } \\
\text { political participation. }\end{array}$ & 3.63 & 1.86 \\
10 & $\begin{array}{l}\text { The customs, traditions and the dominant beliefs are } \\
\text { difficulties for the woman political participation. }\end{array}$ & $\begin{array}{l}\text { The insufficient interest in woman political development } \\
\text { limits her participation. }\end{array}$ & 4.44 \\
11 & $\begin{array}{l}\text { The tribe and the nepotism are important factors limiting } \\
\text { her political participation. }\end{array}$ & 4.28 & 1.05 \\
12 & $\begin{array}{l}\text { The woman poor educational level limits her political } \\
\text { participation }\end{array}$ & 2.66 & 1.04 \\
\hline 13 & $\begin{array}{l}\text { slam never encourages the communication between the } \\
\text { man and the woman in the political field }\end{array}$ & 2.32 & 1.12 \\
\hline
\end{tabular}


The second domain: The social and cultural difficulties the limit the political participation of the Jordanian woman

The first item mean was (4.11) and it is considered a high mean.

The second item mean was (2.08) and it's considered an average mean.

The third item until the eleventh item mean was high.

The twelfth item mean was (2.66) and it's considered an average mean.

The thirteenth item mean was (2.32) and it's considered a low mean

Table 3.

\begin{tabular}{|c|c|c|c|}
\hline No & Item & Mean & Standard deviation \\
\hline 1 & $\begin{array}{l}\text { The ineffective participation of the woman in the } \\
\text { political parties is a difficulty for her political } \\
\text { participation. }\end{array}$ & 4.33 & 1.22 \\
\hline 2 & $\begin{array}{l}\text { The democratic development contributed in her } \\
\text { progress in different aspects and encouraged her to } \\
\text { assume administrative positions. }\end{array}$ & 4.28 & 0.99 \\
\hline 3 & $\begin{array}{l}\text { The law didn't provide the woman the full rights to } \\
\text { activate her political role }\end{array}$ & 2.27 & 1.80 \\
\hline 4 & $\begin{array}{l}\text { The quota system contributed in woman occupation of } \\
\text { political positions. }\end{array}$ & 2.87 & 0.86 \\
\hline 5 & $\begin{array}{l}\text { The dominance of the martial laws and the dominant } \\
\text { values contributed in limiting the political woman. }\end{array}$ & 3.15 & 1.23 \\
\hline 6 & $\begin{array}{l}\text { The modern organizations (Noor Al-Husin Foundation } \\
\text { and the Hashemite Jordanian fund for human } \\
\text { development) contributed in the development and the } \\
\text { activation of the administrative role for the woman. }\end{array}$ & 4.22 & 1.73 \\
\hline 7 & $\begin{array}{l}\text { Some regulations and laws aren't active for dealing } \\
\text { with the woman. }\end{array}$ & 3.60 & 1.64 \\
\hline 8 & $\begin{array}{l}\text { The recent political events in the Arab region } \\
\text { contributed in the evolution of woman rob and her } \\
\text { ability to assume. }\end{array}$ & 3.98 & 1.31 \\
\hline
\end{tabular}

The political responsibility

The first item mean was (4.33) and its considered a high mean.

The second item mean was (4.28) and it's considered a high mean.

The third item mean was (2.27) and it's considered a low mean.

The fourth and the fifth item mean was an average mean.

The sixth, seventh and eighth item mean was high.

The third domain: The economical difficulties that limit Jordanian woman participation in the political life.

Table 4.

\begin{tabular}{clcc}
\hline No & \multicolumn{1}{c}{ Item } & Mean & Standard deviation \\
\hline 1 & $\begin{array}{l}\text { The woman economical dependence on the man affected her } \\
\text { political participation. }\end{array}$ & 4.27 & 1.16 \\
2 & $\begin{array}{l}\text { The low financial ability of the woman pushed her to work in } \\
\text { low financial jobs which lessened her chance to occupy } \\
\text { administrative positions }\end{array}$ & 4.38 & 0.89 \\
3 & $\begin{array}{l}\text { Poverty and woman low living style forced her to work and } \\
\text { prove her abilities. }\end{array}$ & 3.88 & 1.36 \\
4 & $\begin{array}{l}\text { The woman un ability to afford the financial burdens for the } \\
\text { nomination and the electoral campaigns. }\end{array}$ & 3.85 \\
5 & $\begin{array}{l}\text { The inequality between the male and Female candidates in } \\
\text { funding the electoral campaigns. }\end{array}$ & 0.97 \\
6 & $\begin{array}{l}\text { In sufficient contribution by the feminist organizations in } \\
\text { funding the electoral campaigns for the female candidates is } \\
\text { one of the difficulties for her political participation. }\end{array}$ & 3.89 & 0.88 \\
7 & $\begin{array}{l}\text { The woman economical dependence is a direct abstract for her } \\
\text { political participation. }\end{array}$ & 3.98 \\
8 & $\begin{array}{l}\text { The Jordanian woman couldn't risk leaving her work to } \\
\text { nominate for the parliament because it's not guaranteed which } \\
\text { limits her political participation. }\end{array}$ & 3.23 & 1.08 \\
\hline
\end{tabular}


The first item mean until the six items was a high mean.

The sixth - seventh and the eighth items mean was an average mean.

The fourth domain: The ness media difficulties that limit the Jordanian woman political participation

Table 5 .

\begin{tabular}{clcc}
\hline No & \multicolumn{1}{c}{ Item } & Mean & Standard deviation \\
\hline 1 & $\begin{array}{l}\text { The focus of the media directed to the woman on the } \\
\text { traditional social roles limits her political participation. }\end{array}$ & 3.33 & 0.66 \\
2 & $\begin{array}{l}\text { The media deals with woman issues infectively and } \\
\text { superficially }\end{array}$ & 3.87 & 1.44 \\
$3 \quad \begin{array}{l}\text { The media negloctence for the woman role in the } \\
\text { political life limits her political participation. }\end{array}$ & 3.23 & 0.89 \\
$4 \quad \begin{array}{l}\text { The insufficient attention by the media for the woman } \\
\text { especially the political aspect limits her participation. }\end{array}$ & 2.34 & 1.11 \\
5 & $\begin{array}{l}\text { The media presentation of the dependent traditional } \\
\text { woman image who consumes make ups and other things. }\end{array}$ & 3.33 & 1.85 \\
$6 \quad \begin{array}{l}\text { There are to educating program mes directed to the } \\
\text { woman }\end{array}$ & 3.86 & 0.87 \\
7 & $\begin{array}{l}\text { The media can be a positive factor leading to strengthen } \\
\text { her participation or negative factor leading to weaken } \\
\text { her. }\end{array}$ & 4.38 & \\
\hline
\end{tabular}

The First item mean was (3.33) and it's considered an average mean.

The second item mean was (3.87) and it's considered a high mean.

The third until the fifth item mean was an average mean.

The sixth and the seventh items mean was a high mean.

Second: It for the effect of the study variable on the findings, the statistical analysis showed the following:

Table 6. Social status variable

\begin{tabular}{cccc}
\hline Degrees square & Square mean & F value & Statistical significance \\
\hline 0.315 & 0.142 & 0.580 & 0.694 \\
3067 & 0.324 & & \\
5.30 & & & \\
\hline
\end{tabular}

There is no significant statistical relation due to social status variable. The study found that alpha significance is 0.694 and this indicates no significance for the age variable.

Table 7. The academic degree

\begin{tabular}{cccc}
\hline Mean & Standard deviation & F value & Statistical significance \\
\hline 4.17 & 1.13 & $2.22-$ & \\
$4.23-$ & 3.15 & $2.22-$ & 0.713
\end{tabular}

There is no significant statistical relation due to academic level variable. The analysis showed that alpha significance is higher than $(0.05)$ and this indicates no significance for this variable.

Table 8. The administrative level variable

\begin{tabular}{cccc}
\hline Degrees square & Square mean & F value & Statistical significance \\
\hline 3.435 & 0.213 & 0.779 & 0.624 \\
2.97 & 0.325 & & \\
3.55 & & & \\
\hline
\end{tabular}

There is no significant statistical relation due to job variable. The analysis showed that alpha significance is 0.635 and this indicates no significance for this variable. 
Table 9. Job variable

\begin{tabular}{cccc}
\hline Degrees square & Square mean & F value & Statistical significance \\
\hline 3.22 & 0.241 & 0.35 & 0.635 \\
0.67 & 0.118 & & \\
0.92 & & & \\
\hline
\end{tabular}

There is no significant statistical relation due to job variable. The analysis showed that alpha significance is 0.635 and this indicates no significance for this variable.

Table 10. Age variable

\begin{tabular}{llll}
\hline Degrees square & Square mean & F value & Statistical significance \\
\hline 3.191 & 0.330 & 1.44 & 0.031 \\
3.41 & 0.414 & & \\
0.35 & & & \\
\hline
\end{tabular}

There is no significant statistical relation due to age variable. The analysis showed that alpha significance is 0.031 and this indicates no significance for age 40 or more.

Table 11. Monthly income variable

\begin{tabular}{cccc}
\hline Degrees square & Square mean & F value & Statistical significance \\
\hline 1.25 & 0.325 & 0.249 & 0.725 \\
4.8 & 0.244 & & \\
5.66 & & & \\
\hline
\end{tabular}

There is no significant statistical relation due to monthly income variable. The analysis showed that alpha significance is 0.758 and this indicates no significance for monthly income variable.

Table 12. The number of the family member's variable

\begin{tabular}{cccc}
\hline Degrees square & Square mean & F value & Statistical significance \\
\hline 0.233 & 0.442 & 0.177 & 0.741 \\
0.62 & 0.878 & & \\
4.31 & & & \\
\hline
\end{tabular}

There is no significant statistical relation due to family member's number. The analysis showed that alpha significance is 0.741 and this indicates no significance for this variable.

\section{Results and Discussion}

First: what are the most important cultural and social difficulties that face the Jordanian woman participation in the political life from the view point of the pioneer woman? The following items had high means which make them the strongest cultural and social difficulties that limit the woman political participation on they are:

The man doesn't accept the woman to be administratively responsible for him. This reflects on the Jordanian woman participation in the political life and prevents her from the active participation.

The woman lack of awareness and the trust in her abilities in the political work are of the difficulties for her political participation. The woman awareness for her role and abilities provides her with more trust to actively participate in the political life.

The dominant values force the man to protect the woman which decreases her freedom in taking her political decisions. This is conceded as one of the political difficulties in the political life because the Jordanian society is a conservative one in its customs and traditions where the man is like a guardian for the woman the thing that decreases her participation in the political life.

The Jordanian woman is still working in the traditional works that are an extension for her female nature. The woman work is still restricted to certain fields such as nursing education ...etch that allow the woman female opportunism to develop herself and progress in the political participation.

The vice culture is one of the direct factors that limit her political participation. The vice culture determine the nature of the work the woman can practice since the Jordanian society views many of the female activities and 
works as forbidden which in turn decreases her participation in the political life.

The society lack of awareness for he extension or woman political participation. The society didn't reach an enough level of awareness that encourages the woman to participate more in the political life.

The dominant customs- beliefs and traditions are one of the difficulties for woman political participation because many of them don't promote the woman to occupy leadership roles or political roles.

The insufficient interest in woman political development and her education limit her political participation. The woman development in our societies is controlled by the customs and the traditions that don't support liberating her from the traditional roles as a wife and a mother ...etc which in turn don't encourage her to politically participate.

The tribes and nepotism are important factors that kinder woman political participation. The tribe and nepotism had her strong roots in our society. They depend on the man without supporting the woman to engage in the political process.

The following items had an average means which indicate that they are social and cultural difficulties with an average level in limiting woman political participation:

The woman isn't able to balance between the family responsibilities and her political responsibilities. The responses showed that this item is one of the difficulties that prevent the woman from the political participation.

The woman poor educational level is one of the difficulties that limit the woman participation in the political life but this difficulty isn't strong because the woman in our society is having good educational level.

The following item had a low mean that is the Islam never encourages the communication between the man and the woman in the political field. According to sample responses, Islam doesn't reject woman participation in the political work beside the man because the Islamic history had lots of examples about woman participation in the agreements, stating opinions and even wars.

Second: the results related to the second question: what are the most important legal and political difficulties that limit Jordanian woman participation in the Political life?

\section{Conclusions}

\subsection{The Following Items Had High Means}

The ineffective participation of the woman in the political parties is one of the difficulties for her political participation.

The democratic development contributed in her progress in different aspects and encouraged her to assure administrative positions. The study sample agreed with this idea because he recent period witnessed some kind of progress in encouraging the woman to occupy administrative positions.

The modern organizations (Noor Al-Husin foundations and the Hashemite Jordanian fund for human development) contributed in the development and the activation of the administrative role for the woman. The study sample supported this idea since these organizations played an effective role in activating the woman political and administrative role. Some regulations and laws orient active for dealing with the woman. A large present of the study participants supported this item because they thought there are laws and regulation that encourage the woman to politically participate but they are in effective.

The recent political events in the Arab region contributed in the evolution of woman role and her ability to assume the political responsibility. This item had a high agreement due to recent woman effective participation in the local and Arab political life.

\subsection{The Following Items Had an Average Means}

The quota system contributed in woman occupation or political positions. The average support for this item can be the weak presence for the woman in the political life.

The dominance of the martial laws and the dominant values contributed in limiting the political woman. These martial laws more dominant not long time ago which prevented the woman from the political participation because she fears to be perished.

\subsection{The Following Item Had a Law Mean}

First, the law didn't provide the woman the full rights to activate her political role. However, the opposite is the true thing because the law granted the woman complete rights to actively participate in the political life which formed a motivation rather than a difficulty for woman participation in the political life. 
Second, the results related to the third question: what are the most important economical difficulties that limit Jordanian woman participation in the political life?

Third, the following items had high means:

The woman economical dependence on the man affected her political participation our society believes that woman always depends on the man, so she doesn't have the freedom to use the money which is an obstacle for her political participation.

The low financial ability of the woman pushed her to work in low financial jobs which lessened her chance to occupy administrative positions. This made woman less able to move toward the political process.

Poverty and woman low living style forced her to work and prove her abilities. They forced the woman to work next to the man.

The following items from the economical difficulties had an average means which made them from the difficulties which limit woman political participation:

The woman economical dependence is a direct obstacle for her political participation. The woman in our society depends economically on the man and her thinking an any political participation is related to man financing which limits her political participation.

The Jordanian woman couldn't risk leaving her work to nominate for the parliament because it's not guaranteed which limits her political participation. The study samples supported strongly this idea especially that the qualified woman to run the parliament elections won't higher her job.

Fourth: the results related to the fourth question: what are the most important mass media difficulties that limit Jordanian woman participation in the political life?

The following items had high means which make them the strongest media difficulties that limit Jordanian woman participation in the political life:

The media deals with woman issues ineffectively and superficially and the local of programs directed to the woman that discuss educating the woman about the political participation.

The media can be a positive factor leading to strengthen her participation or negative factor leading to weaken her. The media play an important role in educating the woman or not which affects strongly her participation in the political work.

The following items had an average means that make them media difficulties with an average level:

The focus of the woman directed to the woman on the traditional roles limits her political participation which prevents her political participation. The media focus more on the woman traditional role cache as fashion, beauty and make ups.

The media neglectence for the woman role in the political life limits her political participation. This thing hinders her sense of responsibility regarding the political participation.

The media presentation of the dependent woman image who consumes make ups and other things.

Fifth: the results related to the study variables:

The results showed the following:

1- There is no effect for the following variables; social status, the academic degree, the administrative level, job, monthly income and number of family members.

2- The study found an effect for the age variable for the benefit of 40 years and more

\section{Recommendations}

1- The need for educating the society to change its believe regarding the woman participation in the political process.

2- The need to enhance the economical status for the woman through providing the opportunities for her to establish the projects and to occupy more position.

3- The activation of laws and regulations that give the woman her right in the active participation in the political process.

4- The preparation of media programs that target the woman, address her untraditional roles and increase her awareness regarding her participation in the political work. 
5- The conduction of further studies and researches that address the un engagement of the woman in the political life and offering solutions for this problem.

\section{References}

Abu-Hind, Hang. (2003). The psychological and creative features for the working woman in the leadership positions in Amman. Master thesis, Jordan University, Amman.

Abu-Shhir, Hamid. (1994). The woman and the political rights in Islam. Master thesis, Jordan University, Human.

Al- Naqbachandi, Borah. (2003). The Jordanian woman political participation.

Al- Salhi, Susan. (1994). The social difficulties for Jordanian woman participation in the political process: A field study in Amman. Master thesis, Jordan University, Amman, Jordan.

Al-Hadad, Mohammad. (2005). Al-Tahera magazine.

Al-Jassem, Mathal. (1999). The Arab woman role in the political life: A study for the Arab woman status after 1968 revolution. Master thesis, Al-Mustanser University, Baghdad, Iraq.

Al-Khaz, Ali, Nadra. (2005). The woman right to participate in elected parliament. Master thesis, Al-Bait University, Jordan.

Al-Masrawi, Faten. The factors affecting the leading role for the woman in the Jordanian society from the view point of male and female leaders. Master thesis, Yarmouk University.

Al-Mutair, Muna. (1997). The political rights and Islam decision regarding woman assuring them. Master thesis, Human, Jordan.

Al-Tajkani. (1999). the woman right and her duties in Islam.

Al-Thaher, Ahmad Jamal. (1985). The social and political development in the Arab world. Al-Monova library, AL-Zarqa.

Ashour, Iyass. (2003). The political participation of the Jordanian woman (1989-2001). Master thesis, Jordan University, Amman, Jordan.

Baur and ling. (2003). The effect of the political woman role.

Faraj, Karoulin. (1996). The woman guide in the public and political life. Al-Kutbi Centre.

Husin, saridy. (2005). The Palestinian woman and the public and political rights.

Maria, Jamal. (1996). The youth and the political participation in the Jordanian society. Master thesis, Jordan University, Amman, Jordan.

Mohammad- Al-Abadi. (2002, September 19). The woman and the parliament elections. Al-Rai daily newspaper, p. 16.

Mohammad, Bashir. (2001). The woman legal rights in the personal status law. Master thesis, Jordan University - Amman, Jordan.

Rouhi, Reham. (1995). The female movement and its role in the Jordanian society. Master thesis, Jordan University.

Saleh, samya. (2004). The woman political participation and the social change powers (1st ed.). Education faculty, Ein shams university.

The strategic studies centre - Jordan University. (1994). The Jordanian attitudes toward woman participation in the political life.

Zaghloula, Kahlil. (1996). The woman image in media: The Jordanian television during the period between 1/1/1992 to 31/12/1994. Master thesis, Jordan University, Amman- Jordan. 